Article

\title{
Oxidative Assets Toward Biomolecules and Cytotoxicity of New Oxindolimine-Copper(II) and Zinc(II) Complexes
}

\author{
Maurício Cavicchioli ${ }^{1}$, Aline Monteiro Lino Zaballa ${ }^{1}$, Queite Antonia de Paula ${ }^{1}$, \\ Marcela Bach Prieto ${ }^{2}$, Carla Columbano Oliveira ${ }^{2}{ }^{10}$, Patrizia Civitareale ${ }^{3}$, Maria Rosa Ciriolo ${ }^{3}$ \\ and Ana Maria Da Costa Ferreira $1, * \mathbb{D}$ \\ 1 Departamento de Química, Instituto de Química, Universidade de São Paulo, São Paulo 05508-000, SP, Brazil; \\ mauriciocavicchioli@gmail.com (M.C.); alinezaballa@usp.br (A.M.L.Z.); qdepaula@gmail.com (Q.A.d.P.) \\ 2 Departamento de Bioquímica, Instituto de Química, Universidade de São Paulo, \\ São Paulo 05508-000, SP, Brazil; marbp@usp.br (M.B.P.); ccoliv@iq.usp.br (C.C.O.) \\ 3 Dipartamento di Biologia, Università Tor Vergata di Roma, 00133 Roma, Italy; civitare@uniroma2.it (P.C.); \\ ciriolo@uniroma2.it (M.R.C.) \\ * Correspondence: amdcferr@iq.usp.br; Tel.: +55-11-3091-9147 or +55-11-2648-1681
}

Received: 30 October 2018; Accepted: 17 January 2019; Published: 26 January 2019

\begin{abstract}
A new oxindolimine ligand derived from isatin (1H-indole-2,3-dione) and 2-aminomethylbenzimidazole was synthesized, leading to two novel complexes after metalation with copper(II) perchlorate or zinc(II) chloride, $\left[\mathrm{Cu}\left(\right.\right.$ isambz $\left._{2}\right]\left(\mathrm{ClO}_{4}\right)_{2}$ (complex 1) and $\left[\mathrm{Zn}(\right.$ isambz $\left.) \mathrm{Cl}_{2}\right]$ (complex 2). This new ligand was designed as a more lipophilic compound, in a series of oxindolimine-metal complexes with antitumor properties, having DNA, mitochondria, and some proteins, such as CDK1 kinase and topoisomerase IB, as key targets. The new complexes had their reactivity to human serum albumin (HSA) and DNA, and their cytotoxicity toward tumor cells investigated. The binding to CT-DNA was monitored by circular dichroism (CD) spectroscopy and fluorescence measurements using ethidium bromide in a competitive assay. Consequent DNA cleavage was verified by gel electrophoresis with complex $\mathbf{1}$, in nmolar concentrations, with formation of linear DNA (form III) after $60 \mathrm{~min}$ incubation at $37^{\circ} \mathrm{C}$, in the presence of hydrogen peroxide, which acts as a reducing agent. Formation of reactive oxygen species (ROS) was observed, monitored by spin trapping EPR. Interaction with HSA lead to $\alpha$-helix structure disturbance, and formation of a stable radical species (HSA-Tyr.) and carbonyl groups in the protein. Despite showing oxidative ability to damage vital biomolecules such as HSA and DNA, these new complexes showed moderate cytotoxicity against hepatocellular carcinoma $\left(\mathrm{HepG}_{2}\right)$ and neuroblastoma (SHSY5Y) cells, similarly to previous compounds in this series. These results confirm DNA as an important target for these compounds, and additionally indicate that oxidative damage is not the leading mechanism responsible for their cytotoxicity. Additionally, this work emphasizes the importance of ligand characteristics and of speciation in activity of metal complexes.
\end{abstract}

Keywords: isatin-derived ligands; oxindolimine-metal complexes; DNA cleavage; HSA oxidation; cytotoxicity; antiproliferative activity

\section{Introduction}

Cancer is a very important cause of death globally, according to the World Health Organization (WHO) [1]. It corresponds to a large group of diseases, affecting different organs, with slow through to very quick progression. Although platinum complexes are the only metallodrugs approved by Food and Drug Administration (FDA) for clinical use against cancer [2], different metal complexes have 
been developed as alternatives, trying to bypass induced resistance and severe toxic effects [3]. Besides platinum, ruthenium, copper, gold, and vanadium compounds are being extensively investigated. Furthermore, different targets have been identified in wide-ranging studies, depending on the metal and on the ligand.

A primary target in such studies is DNA, and different metal complexes exhibit quite different binding constants, depending on the nature of the metal ion and the structural features of the ligands. Usually, three types of interactions can occur: intercalation, covalent bonds, and electrostatic interactions [4]. For complexes of redox active metal ions, such as iron or copper, oxidative stress plays an important rule, usually causing single and double strand scission by reactive oxygen species (ROS), and can lead to a wide array of DNA lesions implicated in the etiology of many human diseases [5]. Many metal complexes reported as anticancer agents act by an oxidative mechanism involving ROS, in a process modulated by the ligand that is responsible for changes in charge, redox potential, and geometry around the metal, affecting different organelles [6].

However, although most of the reported studies focus on DNA, considerable efforts have been made in unravelling mechanistic details of new metal-based drugs [7], including speciation of the most active compounds, identification of critical regulatory genes, and search for alternative targets. An array of different strategies are being developed to circumvent cancer hallmarks [8]. Most of the potential metallodrugs investigated are multifunctional, interacting with diverse biomolecules. As alternative targets, kinases [9], topoisomerases [10], and histone deacetylases (HDACs) [11] have received high interest in the literature, since these proteins play crucial roles in cell-cycle progression and differentiation, and several types of cancer are associated with deregulation in these activities.

Among the new developed anticancer metal complexes, copper has a deserved special interest, coordinated to a wide range of ligands [12], some of them acting as intercalators to DNA [13] or groove binders [14]. In this scenario, Schiff base complexes have allowed important progress in the field. Classical diimines or Schiff bases, such as phenanthroline and correlated planar ligands, are common examples of DNA intercalators, acting efficiently as artificial metallonucleases [15]. Since many copper compounds show preference for interaction with guanine moieties [16], investigations into new complexes able to act as G-quadruplex DNA binders have increased significantly [17]. Further, there is evidence that G-quadruplex structures are improved in cancer cells compared to healthy ones [18]. Therefore, different metal complexes have been reported interacting with both duplex and quadruplex DNA, especially with Schiff base ligands [19]. Recently, two dinuclear copper(II) complexes based on phenanthroline ligands were shown to promote oxidative damage to DNA and mitochondria through the formation of singlet oxygen and superoxide radicals, causing double strand breaks and mitochondrial membrane depolarization [20]. Furthermore, these compounds are able to discriminate oligomer sequences, mediating Z-like DNA formation.

Isatin (1H-indole-2,3-dione, or 2,3-dioxoindoline), an endogenous oxindole widely distributed in different tissues in mammals, is formed in the metabolism of amino acids such as tryptophan, and some of its derivatives have demonstrated a wide range of effects in biological media, including inhibition of monoamine oxidase, anti-viral, fungicidal, bactericidal, and anti-proliferative activities [21]. Schiff base ligands containing an oxindole group also exhibited pharmacological properties, especially anti-convulsing, anti-depressive, analgesic, and anti-inflamatory activities [22], and these properties were improved when coordinated to metal ions [23]. Further, synthetic isatin derivatives were developed as potent kinase inhibitors, exhibiting good antineoplastic and anti-angiogenesis activities [24,25], and some of them entered into clinical tests [26], being approved by FDA, such as, for instance, sunitinib malate (SU11248; Sutent ${ }^{\circledR}$; Pfizer Inc., New York, NY, USA).

With the aim of preparing new metal complexes that exhibit promising pharmacological or medicinal activity in neoplastic processes, we have designed and isolated some oxindolimines and their corresponding metal complexes, inspired by such oxindole derivatives $[27,28]$. Therefore, we have investigated a series of oxindolimine-metal complexes as pro-apoptotic compounds toward 
different tumor cells, trying to elucidate their possible modes of action and verifying their potential as alternative antitumor agents.

As delocalized lipophilic cations [29,30], they are able to enter the cell and generate reactive oxygen species (ROS), causing oxidative damage and triggering AMPK-dependent apoptosis in different tumor cells. DNA and mitochondria were reported as their main targets. In more recent studies, a significant inhibition of crucial proteins, kinase (CDK1/cyclin B) [31] and topoisomerase IB [32], was additionally verified, emphasizing the contribution of the ligand to the reactivity of such complexes, and their behavior as multifunctional compounds. Interactions of the ligands at the active cavity of the proteins, mostly through hydrogen bonds and stacking, modulate the activity of such complexes [31,32]. These compounds exhibited high thermodynamic stability when tested using human serum albumin (has) as a competitive biological ligand. The relative stability constants determined for this series of compounds are very similar to those of copper ions inserted at the $\mathrm{N}$-terminal of the protein ( $\mathrm{pK}=12)$ or of zinc ions bound at Cys34 residue $(\mathrm{pK}=7)$ [31].

Herein, a copper(II) and an analogous zinc(II) complex of a new oxindolimine ligand, derived from isatin and 2-aminomethylbenzimidazole and designed to facilitate intercalative interactions, were investigated for their oxidative ability and cytotoxicity toward human hepatocellular carcinoma $\left(\mathrm{HepG}_{2}\right.$ ) and neuroblastomas (SH-SY5Y), trying to improve their antiproliferative properties in relation to previously studied related compounds.

\section{Results and Discussion}

The new complexes, named here $\left[\mathrm{Cu}(\text { isambz) })_{2}\right]^{2+} \mathbf{1}$ and $\left[\mathrm{Zn}(\text { isambz) }]^{2+} \mathbf{2}\right.$, (see Figure 1 ) were prepared according to a similar procedure used in a series of other oxindolimine-metal compounds previously studied $[27,28]$. After characterization by UV/Vis and IR spectroscopies (see Experimental Section), their reactivity versus human serum albumin (HSA) and CT-DNA was investigated.
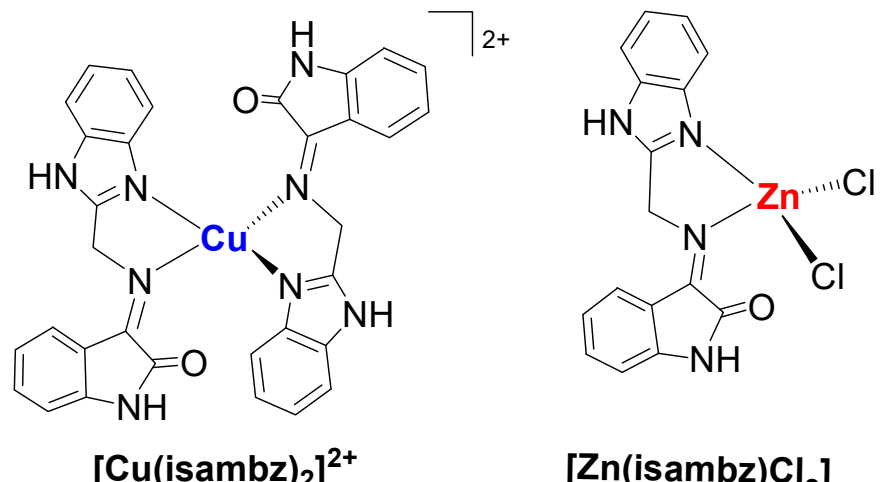

\section{$\left[\mathrm{Zn}(\right.$ isambz $\left.) \mathrm{Cl}_{2}\right]$}

Figure 1. Scheme of the studied complexes, $\left[\mathrm{Cu}(\mathrm{isambz})_{2}\right]^{2+} \mathbf{1}$, and $[\mathrm{Zn}(\mathrm{isambz})]^{2+} \mathbf{2}$.

The copper(II) complex was isolated as 1:2 species, with ligands in the keto form, while the analogous zinc(II) was obtained as the 1:1 species, with the ligands in the enol form. Both species can be obtained by controlling the $\mathrm{pH}$ of the solution during the syntheses. However, in solution there is an equilibrium (Scheme 1) between those two forms depending on the $\mathrm{pH}$, involving tautomeric forms of the ligands, similarly to what was observed in correlated complexes [28].

In further experiments, the analogous copper(II) compound $\left[\mathrm{Cu}(\mathrm{isambz}) \mathrm{ClO}_{4}\right.$ was isolated and the EPR spectra of both copper(II) species were compared in order to clarify their structural features. Based on the spectroscopic parameters determined, the compound 1:2 showed a more tetrahedral distorted structure $\left(\mathrm{g}_{/ / /} / \mathrm{A}_{/ /}=182 \mathrm{~cm}\right)$, while the complex 1:1 exhibited a tetragonal configuration $\left(\mathrm{g}_{/ / /} / \mathrm{A}_{/ /}=116 \mathrm{~cm}\right)$, according to a semi-empirical approach [33].

Initially, the ability of the copper complex 1 in generating reactive oxygen species (ROS) was tested after 10 min incubation of this complex with hydrogen peroxide, by EPR measurements, using the spin trapping method. In Figure 2, it can be seen that up to $150 \mu \mathrm{M}$ this complex is not very oxidative, 
forming a limited amount of hydroxyl radicals, as detected by DMPO-OH adducts. However, in complementary experiments at much lower concentrations, it was able to oxidize HSA, as monitored by carbonyl groups formation through reaction with DNPH.

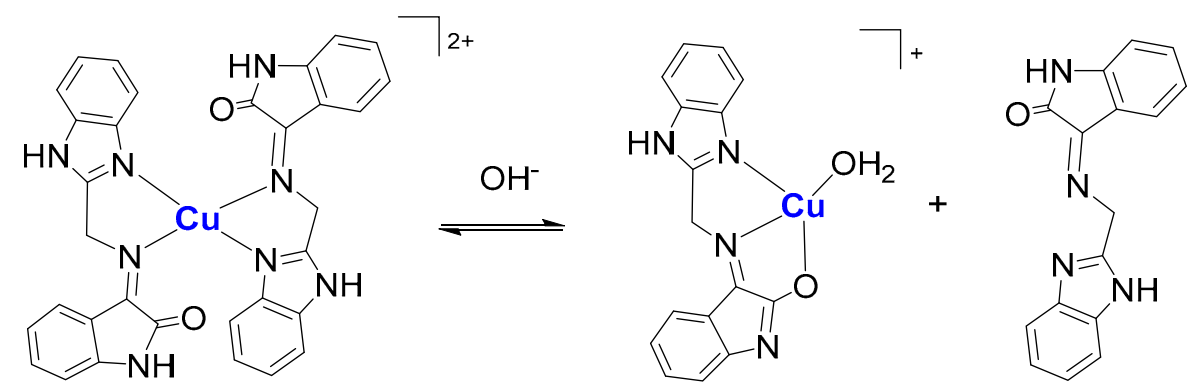

Scheme 1. Equilibrium involving tautomeric forms of oxindolimine ligands coordinated to copper(II) ions.
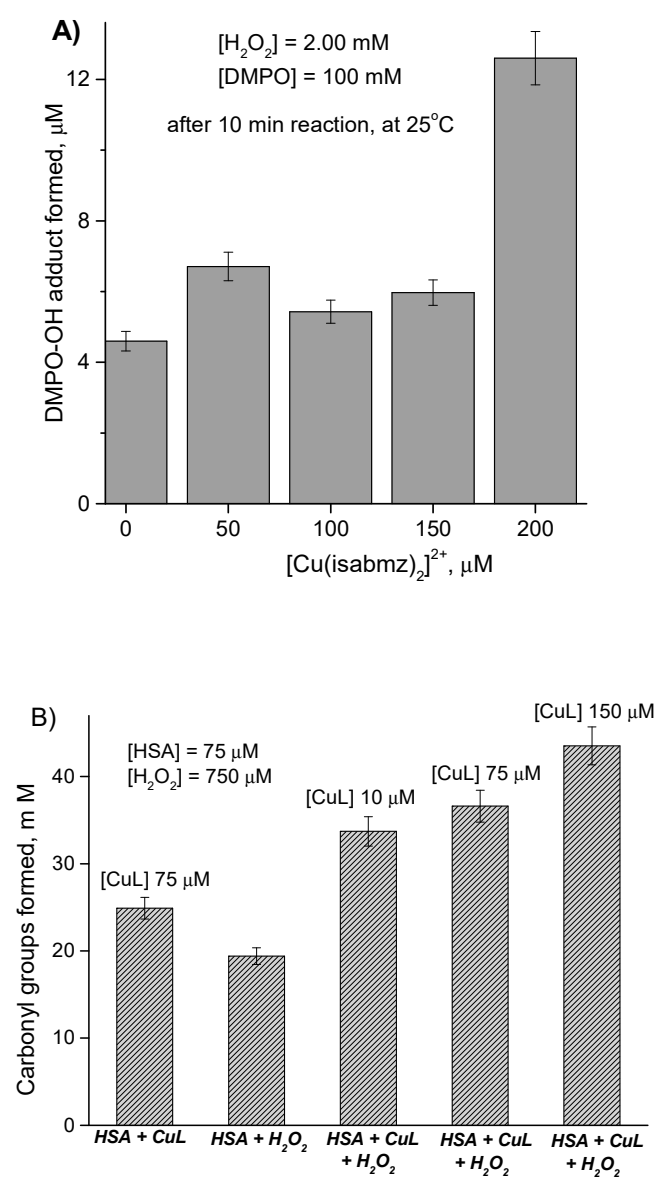

Figure 2. (A) Double integrated signal of 5,5-Dimethyl-1-pyrroline N-oxide (DMPO)-OH adduct detected by EPR spectroscopy after $10 \mathrm{~min}$ reaction in phosphate buffer at $\mathrm{pH}$ 7.4, at room temperature, using DMPO $(100 \mathrm{mM})$ as spin trap, in the presence of complex $\left[\mathrm{Cu}(\mathrm{isambz})_{2}\right]^{2+} \mathbf{1}$ (50 to $\left.200 \mu \mathrm{M}\right)$ and $\mathrm{H}_{2} \mathrm{O}_{2}(2.0 \mathrm{mM}$ ); (B) Oxidative damage to human serum albumin (HSA, $75 \mu \mathrm{M}$ ) induced by complex $\left[\mathrm{Cu}(\text { isambz })_{2}\right]^{2+} \mathbf{1}$ after incubation for $30 \mathrm{~min}$ at $37^{\circ} \mathrm{C}$ in the presence of hydrogen peroxide $(750 \mu \mathrm{M})$, monitored by the formation of carbonyl groups in the protein.

By incubation of the protein with complex $\mathbf{1}$ and hydrogen peroxide, and using EPR spectroscopy, a stable protein-radical species was detected under air, at $\mathrm{g}=1.989$ (line width of $52 \mathrm{G}$ ), as shown in Figure 3. A very similar species $(g=1.996$, line width of $45 \mathrm{G}$ ) was obtaining by using an analogous complex, $\left[\mathrm{Cu}(\text { isaepy })_{2}\right]^{2+}$, one of the most reactive in a series of such copper(II) complexes $[29,30]$. 
Studies on the oxidation of bovine serum albumin (BSA) by Cu,Zn-superoxide dismutase (SOD1) and hydrogen peroxide in the presence of nitrite, have identified a similar radical ( $g=2.007$; total line width of $54 \mathrm{G}$ ) [34]. This protein-bound radical is very stable, detectable at room temperature and under air, and was identified as a protein-Tyr. species. It was also reported in the heme detoxification process by HSA, inhibiting further destructive or irreversible oxidation of the protein [35].
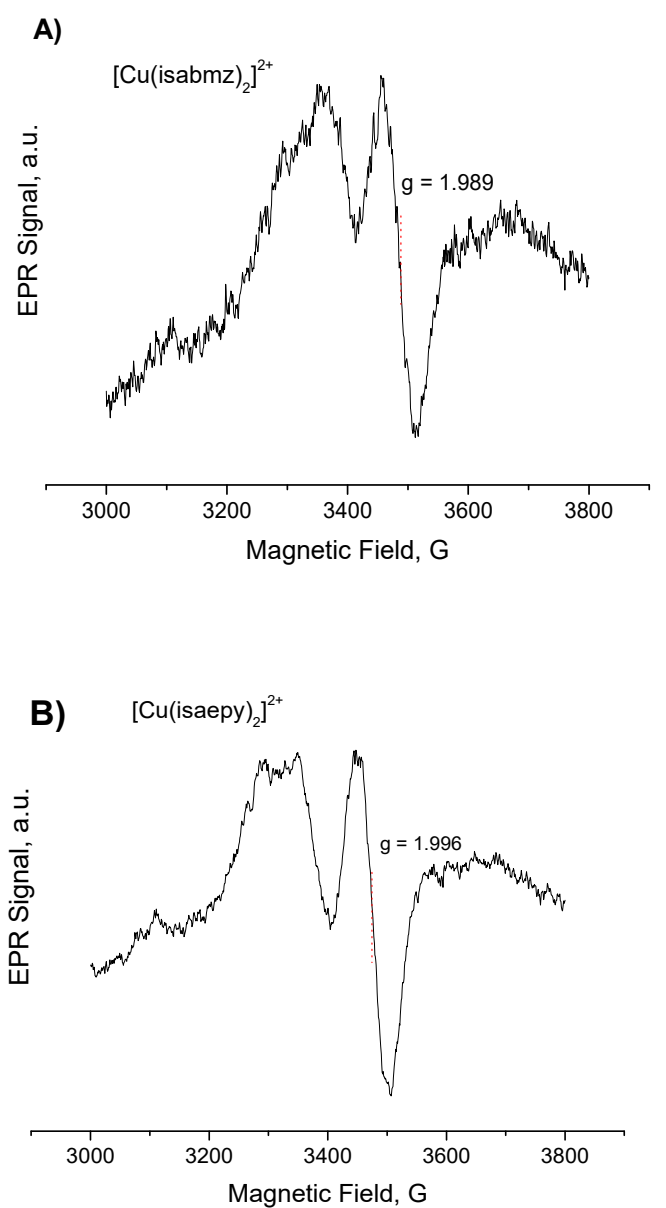

Figure 3. EPR spectra of radical species formed by oxidation of HSA $(0.600 \mathrm{mM})$, in the presence of $\left[\mathrm{H}_{2} \mathrm{O}_{2}\right]=2.5 \mathrm{mM}$ and each of the complexes $(100 \mu \mathrm{M}),\left[\mathrm{Cu}(\text { isambz })_{2}\right]^{2+} \mathbf{1}(\mathbf{A})$ or $\left[\mathrm{Cu}(\text { isaepy })_{2}\right]^{2+}(\mathbf{B})$.

Further studies by CD spectroscopy showed that by titrating HSA with this copper complex 1, the protein $\alpha$-helix structure is substantially altered, indicating an efficient binding of the complex to the protein (see Figure 4) that probably favors its oxidation.

However, complementary experiments by SDS PAGE (Figure S1, supplementary material) of HSA $(75 \mu \mathrm{M})$ incubated for $30 \mathrm{~min}$ at $37^{\circ} \mathrm{C}$ with each of these copper(II) complexes $(75 \mu \mathrm{M})$, in the presence or in the absence of hydrogen peroxide, did not show degradative damage (cleavage) of the protein. 


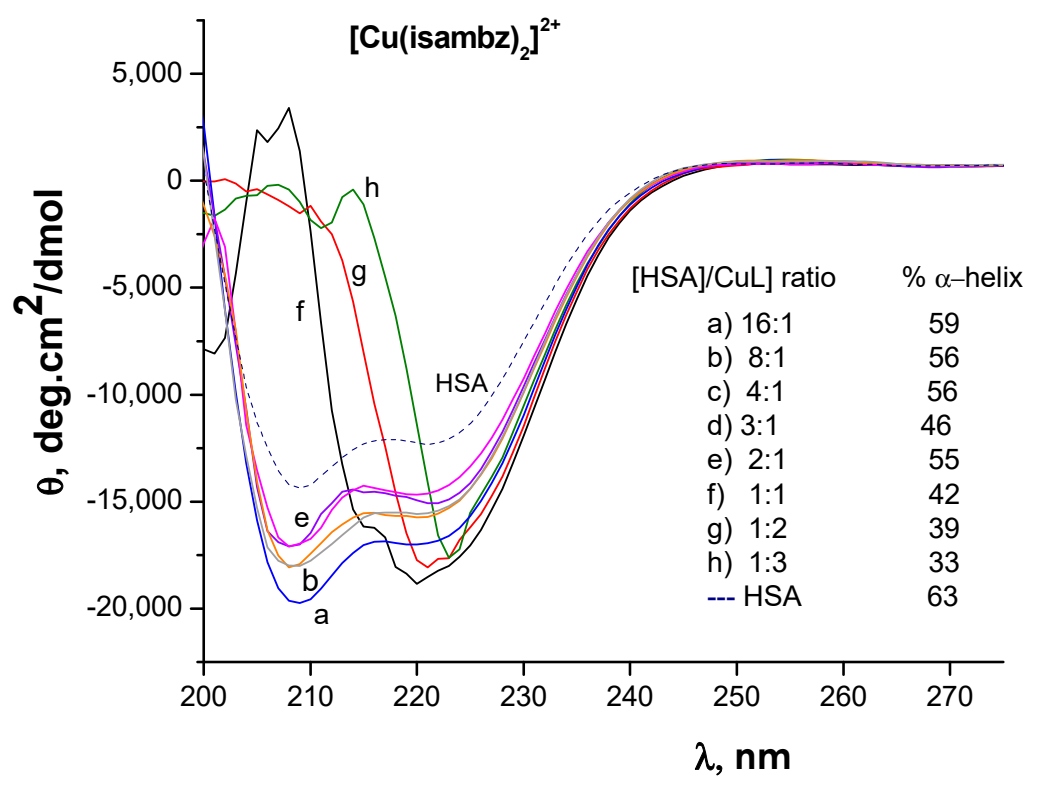

Figure 4. CD spectra registered (double scanning) after increasing concentrations of complex 1 (0.15 to $7.5 \mu \mathrm{M})$, to HSA solution $(2.5 \mu \mathrm{M})$, in phosphate buffer $50 \mathrm{mM}$ containing $0.10 \mathrm{M} \mathrm{NaCl}$, at pH 7.4, at room temperature.

\subsection{Quenching of DNA-EtBr Fluorescence}

Since one of the most studied targets for metal complexes is DNA, we verified by fluorescence measurements the ability of both complexes to bind to CT-DNA saturated with ethidium bromide (EtBr), a known nucleic acid intercalator.

Results in this competitive assay revealed that changes in fluorescence were more noticeable for complex 1 than for complex 2 at high concentrations of quencher [Q], as shown in Figure 5 . By using two methods, Stern-Volmer plots of $F_{0} / F$ versus [Q], and logarithmic Scathchard graphs, $\log \left(F_{0}-F\right) / F$ versus $\log [Q]$, the corresponding binding constants $K_{\mathrm{SV}}$ as well as $K_{\mathrm{a}}$ and binding site number $n$ were determined. The values of $K_{\mathrm{SV}}$ was obtained by linear fitting up to $400 \mu \mathrm{M}[\mathrm{Q}]$ and was higher for the copper complex $1\left(4.52 \times 10^{2} \mathrm{M}^{-1}\right)$ than for the zinc complex $2\left(2.75 \times 10^{2} \mathrm{M}^{-1}\right)$, suggesting a stacking or intercalative interaction. The difference observed can be probably attributed to a more planar structure of the copper compound relative to that of zinc, enabling an intercalation among bases.

However, for both complexes a non-collisional quenching seemed to work, as indicated by the curves obtained in Scathchard graphs (see Figure 5). A linear plot indicates a single quenching mechanism, while a positive deviation points to different binding sites in the biomolecule available for the quenchers, usually with different affinities.

The corresponding parameters, $K_{\mathrm{a}}$ and $n$, were determined and were very low when compared to analogous values previously obtained for a series of similar Schiff base-copper(II) complexes, $\left[\mathrm{Cu}(\text { isaepy })_{2}\right]^{2+},\left[\mathrm{Cu}(\mathrm{enim}) \mathrm{H}_{2} \mathrm{O}\right]^{2+},[\mathrm{Cu}(\text { isaenim })]^{2+}$, and $\left[\mathrm{Cu}(o-\text { phen })_{2}\right]^{2+}$ in competitive experiments with EtBr intercalated in plasmidial DNA (see Table 1) [36]. Furthermore, in the case of plasmidial DNA, the observed $K_{\mathrm{a}}$ values are usually lower (100-fold) than for CT-DNA. For all the complexes in previous series, an efficient interaction with DNA structure was verified, with $K_{\mathrm{a}}$ in the range of $10^{2}$ and $n$ between 0.5 and 1 . However, for the new complexes 1 and 2 , these parameters are too low, with $K_{\mathrm{a}}$ in the range of $10^{-1}$ and $n$ between 0.2 and 0.3 , indicating little binding to DNA, that is, little competitive substitution of EtBr as DNA intercalator.

The small decrease of fluorescence intensity of EB bound to CT-DNA observed upon increasing addition of the complexes 1 and 2 (up to $400 \mu \mathrm{M}$ ), shown in Figure S2 (supplementary material), corroborates this fact. Additionally, this was reinforced by CD spectra, monitoring the decrease in the 
typical DNA band at 270-280 $\mathrm{nm}$ by increasing addition of the metal complexes, up to $250 \mu \mathrm{M}$ (see Figure 6). Most likely, in the case of complexes focused on herein, the main interactions occur at minor or major grooves, with slight intercalation.
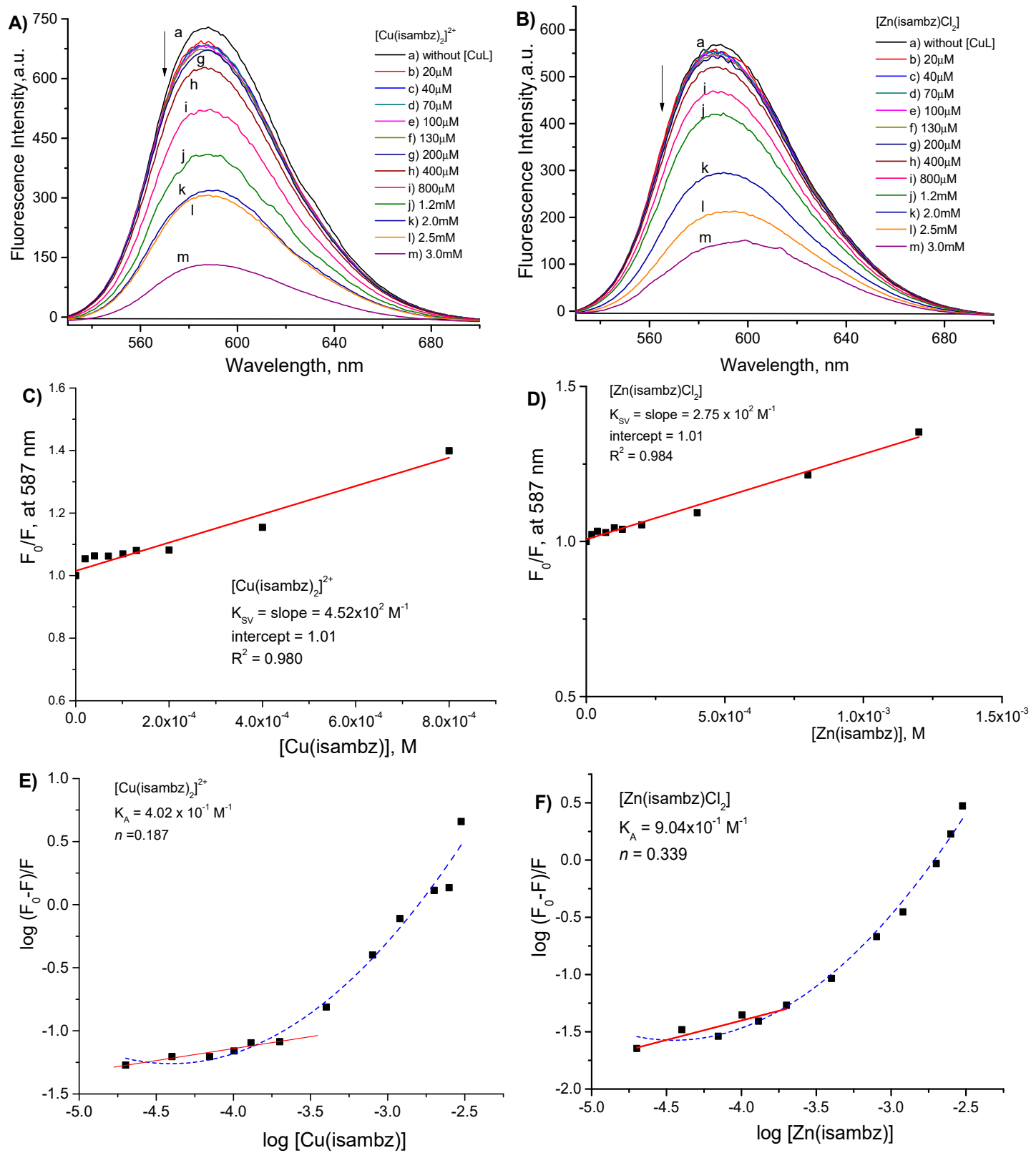

Figure 5. (A,B) Fluorescence emission spectra of EtBr intercalated to CT-DNA, in the absence and in the presence of the complexes $\left[\mathrm{Cu}(\mathrm{isambz})_{2}\right]^{2+} \mathbf{1}$ or $[\mathrm{Zn}(\mathrm{isambz})]^{2+} \mathbf{2}$, respectively. $[\mathrm{EtBr}]=50 \mu \mathrm{M}$; $[C T-D N A]=30 \mu \mathrm{M}$, and quencher concentration varying from 20-3000 $\mu \mathrm{M} ;(\mathbf{C}, \mathbf{D})$ Stern-Volmer equation dependence on the concentration of quenchers, complexes $\left[\mathrm{Cu}(\text { isambz) }]^{2+} \mathbf{1}\right.$ or $\left[\mathrm{Zn}(\text { isambz) }]^{2+}\right.$ 2, respectively; (E,F) Scathchard plots and linear regression fittings to estimate association binding constants, and corresponding binding site number for quenchers, $\left[\mathrm{Cu}\left(\text { isambz) }{ }_{2}\right]^{2+} \mathbf{1}\right.$ or $\left[\mathrm{Zn}(\text { isambz) }]^{2+}\right.$ 2 , respectively. 
Table 1. The quenching constants and binding site number of CT-DNA/EtBr or plasmidial DNA/EtBr* by some Schiff base-copper(II) or zinc(II) complexes.

\begin{tabular}{|c|c|c|c|}
\hline Complex & $K_{\mathrm{SV}}\left(\mathrm{M}^{-1}\right)$ & $K_{\mathrm{a}}, \mathbf{M}^{-1}$ & $N$ \\
\hline$\left[\mathrm{Cu}(\text { isambz })_{2}\right]^{2+}$ & $5.83 \times 10^{2}$ & $4.02 \times 10^{-1}$ & 0.19 \\
\hline$[\mathrm{Zn}(\text { isambz })]^{2+}$ & $2.75 \times 10^{2}$ & $9.04 \times 10^{-1}$ & 0.34 \\
\hline$\left[\mathrm{Cu}(\text { isaepy })_{2}\right]^{2+}$ & - & $3.64 \times 10^{2}$ & $0.68 *$ \\
\hline$\left[\mathrm{Cu}(\mathrm{enim}) \mathrm{H}_{2} \mathrm{O}\right]^{2+}$ & - & $4.13 \times 10^{2}$ & $0.45 *$ \\
\hline$[\mathrm{Cu}(\text { isaenim })]^{2+}$ & - & $8.85 \times 10^{2}$ & $0.73 *$ \\
\hline$\left[\mathrm{Cu}(o-\text { phen })_{2}\right]^{2+}$ & - & $7.55 \times 10^{2}$ & $0.60 *$ \\
\hline
\end{tabular}
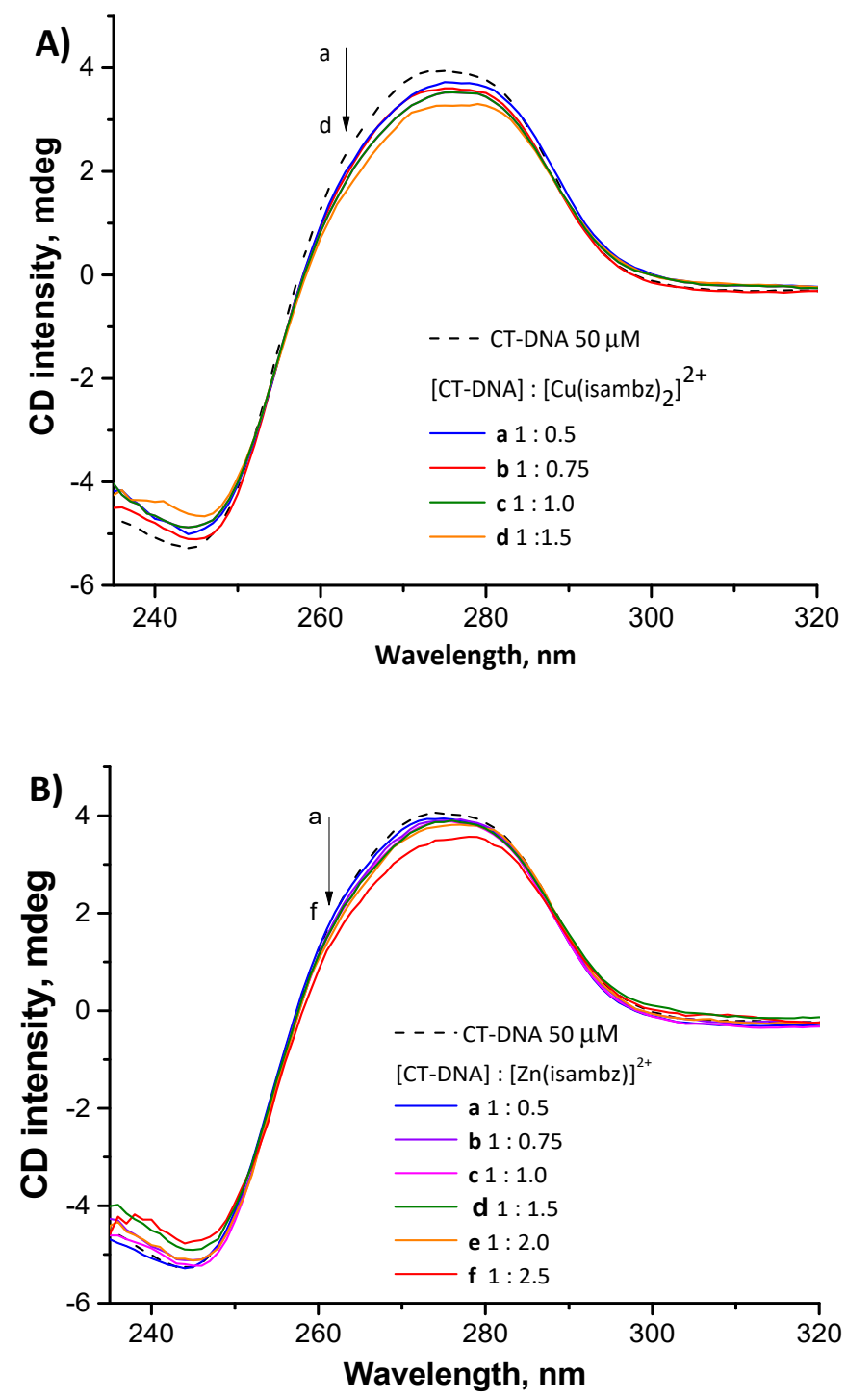

Figure 6. CD spectra of CT-DNA $(50 \mu \mathrm{M})$ in phosphate buffer $50 \mathrm{mM}$ containing $\mathrm{NaCl} 100 \mathrm{mM}$, in the absence and presence of (A) varied concentrations of the copper(II) complex, $\left[\mathrm{Cu}(\text { isambz) }]^{2+} \mathbf{1}\right.$ and (B) varied concentrations of the zinc complex $\left[\mathrm{Zn}(\text { isambz) }]^{2+} \mathbf{2}\right.$.

\subsection{Oxidative Damage to DNA}

Despite not showing very significant interaction with DNA (at low concentrations), significant single and double cleavage of CT-DNA was verified in the presence of hydrogen peroxide $(50 \mu \mathrm{M})$ and complex 1, after incubation for 30 or $60 \mathrm{~min}$ at $37^{\circ} \mathrm{C}$ (see Figure 7). This was the most reactive copper 
complex in an already investigated series of complexes regarding its nuclease activity [37], leading to the linear DNA form III after $60 \mathrm{~min}$, at $50 \mathrm{nM}$. In different experimental conditions, by using $125 \mathrm{mM}$ $\mathrm{H}_{2} \mathrm{O}_{2}$, formation of linear DNA form was observed at $5 \mu \mathrm{M}$ after $12 \mathrm{~h}$ incubation, as also shown in Figure 7.

\section{(A)}

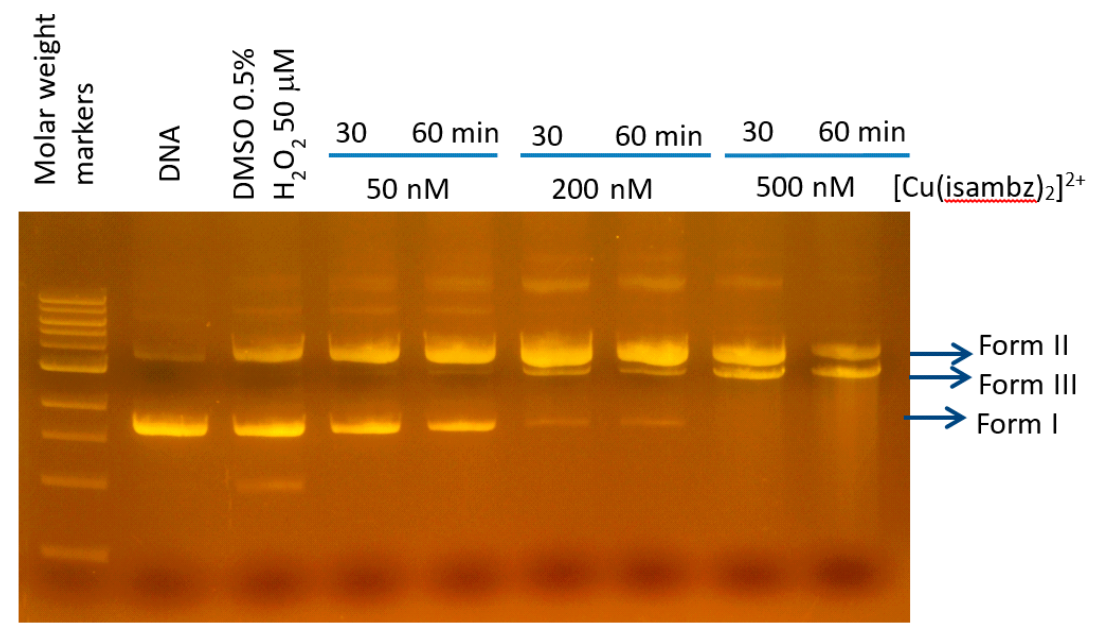

(B)

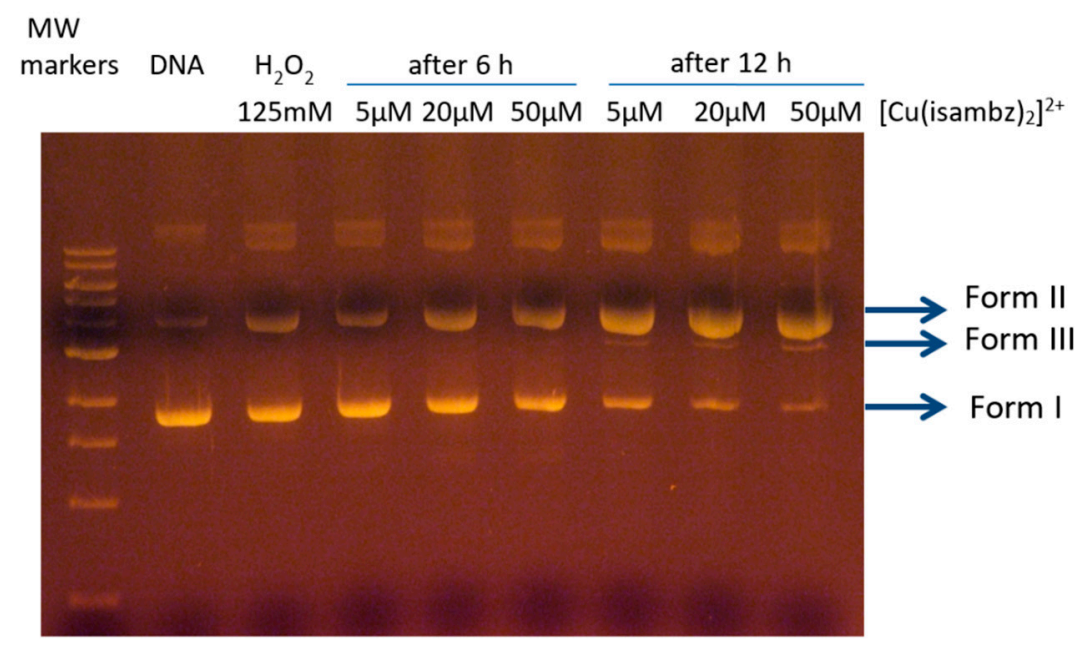

Figure 7. DNA strand double cleavage observed in the presence of $(\mathrm{A})\left[\mathrm{Cu}(\mathrm{isambz})_{2}\right]^{2+}(50,200$, or $500 \mathrm{nM})$, and $\mathrm{H}_{2} \mathrm{O}_{2}(50 \mu \mathrm{M})$, after 30 or 60 min incubation, at $37^{\circ} \mathrm{C}$; (B) $\left[\mathrm{Cu}(\text { isambz })_{2}\right]^{2+}(5,20$, or $50 \mu \mathrm{M})$, and $\mathrm{H}_{2} \mathrm{O}_{2}(125 \mathrm{mM})$, after 6 or $12 \mathrm{~h}$ incubation, at $37^{\circ} \mathrm{C}$. Initial [DNA] $=240 \mathrm{ng}$ of supercoiled DNA (Form I), in $20 \mu \mathrm{L}$ phosphate buffer (50 mM, pH 7.4).

\subsection{Cytotoxicity Toward Tumor Cells}

The antiproliferative properties of the new complexes $\mathbf{1}$ and $\mathbf{2}$ were tested against hepatocellular carcinoma cells ( $\mathrm{HepG}_{2}$ ) and neuroblastoma cells (SHSY5Y), up to $50 \mu \mathrm{M}$ concentration. The compounds showed different cytotoxic effects toward SHSY5Y cells which were more susceptible with respect to the HepG2 cells (Figure 8). In particular, the zinc complex 2 did not significantly affects cell viability of HepG2 cells, but is significantly toxic for SHSY5Y cells only at $50 \mu \mathrm{M}(p<0.01)$. On the contrary, copper complex 1 showed slightly toxic effect at both $25 \mu \mathrm{M}$ and $50 \mu \mathrm{M}$ for HepG2 cells $(p<0.05)$, and a more pronounced toxicity for the SHSY5Y cells at both $25 \mu \mathrm{M}$ and $50 \mu \mathrm{M}(p<0.01)$. Therefore, the cytotoxicity of both complexes was cell type dependent. This behavior is very similar to that 
observed with copper(II) complexes with related ligands derived from isatin [28,29]. Consequently, the introduction of a more lipophilic moiety in the ligand (benzimidazole group) apparently did not significantly improve the cytotoxicity of these complexes, as expected.

In the literature [38], [Cu(o-phen $\left.)_{2}\right]^{2+}$ complex has been reported to induce apoptosis in HepG2 cells by generation of ROS, with $\mathrm{IC}_{50}$ around $5 \mu \mathrm{M}$ after $24 \mathrm{~h}$ incubation at $37^{\circ} \mathrm{C}$. Its higher cytotoxicity can be explained by the almost planar arrangement of the phenanthroline rings that helps its intercalation with DNA [39]. For both of our complexes, the main interactions with DNA probably occurred at minor or major grooves due their structure (distorted tetrahedral geometry).
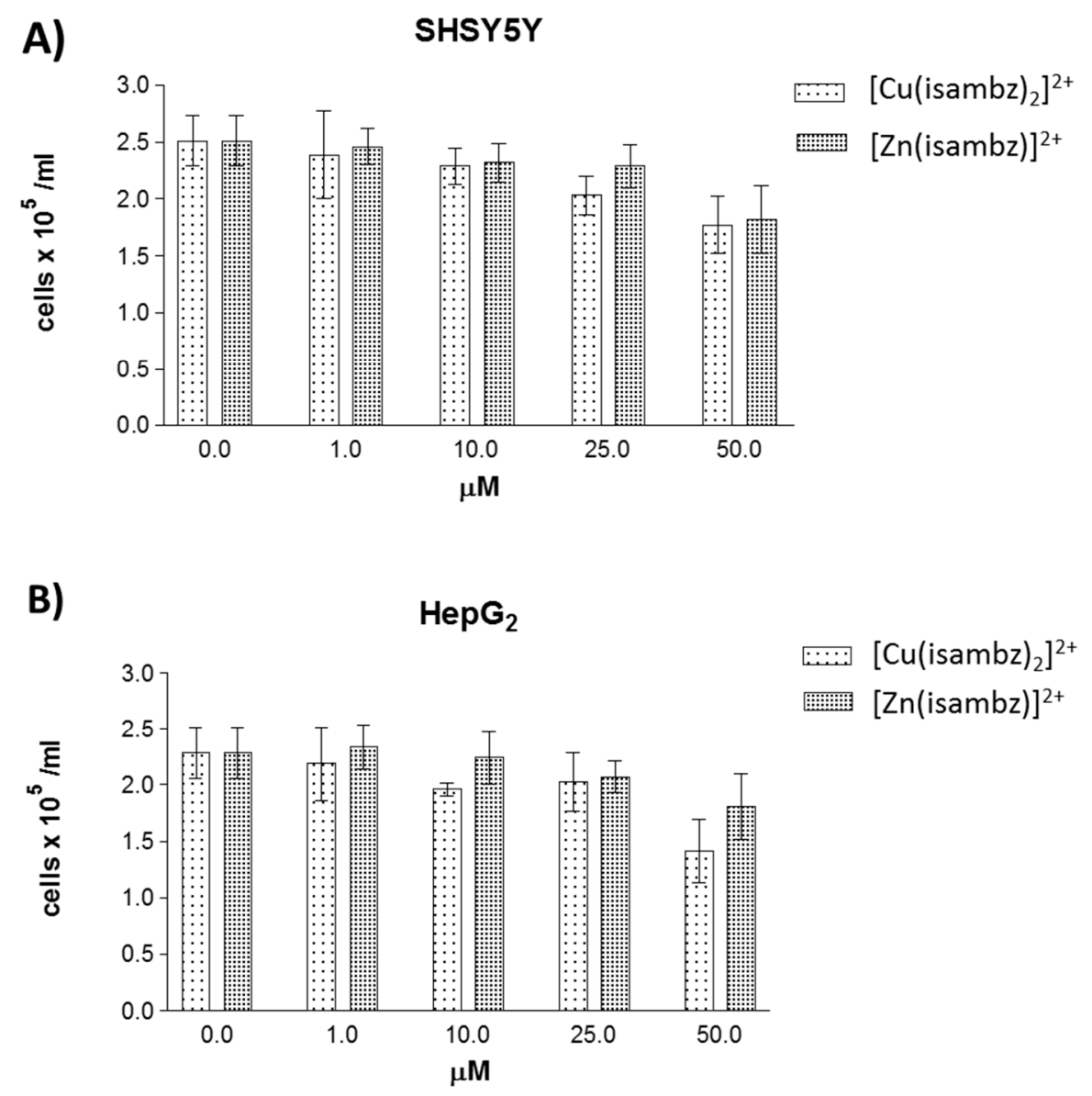

Figure 8. Viability of (A) neuroblastoma SHSY5Y cells, and (B) hepatocellular carcinoma HepG2 cells, after $24 \mathrm{~h}$ incubation at $37^{\circ} \mathrm{C}$ with complexes $\left[\mathrm{Cu}(\text { isambz })_{2}\right]^{2+} \mathbf{1}$ or $[\mathrm{Zn}(\text { isambz })]^{2+} \mathbf{2}$.

\section{Experimental Section}

\subsection{Materials}

The reagents isatin ( $1 H$-indole-2,3-dione, 98\%), 2-(2-aminoethyl)pyridine (95\%), 1,3-diaminopropane (98\%), histamine dihydrochloride (99\%), 2-aminomethylbenzimidazole dihydrochloride (99\%), copper(II) perchlorate hexahydrated (98\%), were purchased from Aldrich Chemical Co. Calf thymus DNA as sodium salt (CT-DNA) and human serum albumin (HSA) were from Sigma-Aldrich (St. Louis, MO, USA), while most of the solvents, ethanol, methanol, and dichloromethane were from Merck Chemical Co. (Darmstadt, Germany). All the solutions were prepared with water purified in a deionizer Barnstead apparatus, model D470. 
Syntheses of the Complexes

The new metal complexes with oxindolimine ligands were prepared by methodology already developed in previous studies, with suitable modifications $[27,28]$. Depending on the $\mathrm{pH}$ during the metalation step, tautomeric forms (keto or enol) of the ligand are preferentially formed and the corresponding metal complexes can be isolated. For complex 1 , the species $\left[\mathrm{CuL}_{2}\right]$ with the ligand in the keto form was isolated at apparent $\mathrm{pH}$ in the range 5 to 7 , while the analogous [ZnL] complex 2, with the ligand in the enol form, was isolated at $\mathrm{pH}$ 9. In previous studies with similar oxindolimine ligands, both complex species 1:2 (ligand in keto form) and 1:1 (ligand in enol form) could also be isolated and characterized [36].

Complex [ $\left.\mathrm{Cu}(\text { isambz })_{2}\right]\left(\mathrm{ClO}_{4}\right)_{2}$ - complex 1: To a solution of isatin $1.47 \mathrm{~g}(10.0 \mathrm{mmols})$ dissolved in $25 \mathrm{~mL}$ ethanol and $25 \mathrm{~mL} \mathrm{CH} \mathrm{Cl}_{2}, 2.20 \mathrm{~g}$ (10.0 mmols) of 2-aminomethylbenzimidazol were added, adjusting the $\mathrm{pH}$ to 5.5 with drops of $\mathrm{HCl}$. The solution was kept under constant stirring for $24 \mathrm{~h}$. Afterwards, the metallation of the formed ligand was carried out by addition of $1.85 \mathrm{~g}$ ( $5.00 \mathrm{mmols})$ copper(II) perchlorate hexahydrate dissolved in $5 \mathrm{~mL}$ water. In this step, the $\mathrm{pH}$ was adjusted around 7 by adding some drops of $\mathrm{NaOH}$ solution, and a brown precipitate was formed. This precipitate was collected after cooling the final solution, washed with cold ethanol and ethyl ether, and finally dried in a desiccator under reduced pressure. The keto form of the ligand coordinated to the copper ion, in a 1:2 metal:ligand complex, was isolated. The yield was $74 \%$ (3.02 g). Elemental analyses: Calc. for $\mathrm{C}_{32} \mathrm{H}_{24} \mathrm{~N}_{8} \mathrm{O}_{2} \mathrm{Cu}\left(\mathrm{ClO}_{4}\right)_{2}(\mathrm{MW}=815.05): \mathrm{C}, 47.16 ; \mathrm{H}, 2.97 ; \mathrm{N}, 13.75 ;$ Experim.: $\mathrm{C}, 48.51 ; \mathrm{H}, 3.05 ; \mathrm{N}, 14.30$. UV/Vis: $\lambda_{\max }=256 \mathrm{~nm}\left(\varepsilon=1.61 \times 10^{-4} \mathrm{M}^{-1} \cdot \mathrm{cm}^{-1}\right), \lambda_{\max }=284 \mathrm{~nm}\left(\varepsilon=1.87 \times 10^{-4} \mathrm{M}^{-1} \cdot \mathrm{cm}^{-1}\right) . \mathrm{IR}$ $\left(\mathrm{cm}^{-1}\right)$ : 3343, $v(\mathrm{~N}-\mathrm{H}) ; 2976, v\left(\mathrm{C}_{\mathrm{sp} 2}-\mathrm{H}\right.$ and $\left.\mathrm{C}=\mathrm{C}\right) ; 1722, v(\mathrm{C}=\mathrm{O}), 1614$ and $1597, v(\mathrm{C}=\mathrm{N}$ Schiff base, isatin ring and $\mathrm{N}-\mathrm{H}) ; 741, v\left(\mathrm{C}-\mathrm{H}\right.$ phenyl). EPR spectra, in DMSO/water at $77 \mathrm{~K}: \mathrm{g}_{\perp}=2.096 ; \mathrm{g}_{/ /}=2.427 ; \mathrm{A} / /$ $=118 \mathrm{G}=133 \times 10^{-4} \mathrm{~cm}^{-1}$ (distorted tetrahedral symmetry). For analogous complex, isolated as 1:1 species $[\mathrm{Cu}(\mathrm{isambz})] \mathrm{ClO}_{4}, \mathrm{EPR}$ spectra, in DMSO $/$ water at $77 \mathrm{~K}: \mathrm{g}_{\perp}=2.107 ; \mathrm{g}_{/ /}=2.450 ; \mathrm{A} / /=186 \mathrm{G}=$ $212 \times 10^{-4} \mathrm{~cm}^{-1}$ (tetragonal symmetry).

Complex $\left[\mathrm{Zn}\left(\right.\right.$ isambz) $\left.\mathrm{Cl}_{2}\right] \cdot \mathrm{H}_{2} \mathrm{O}$ - complex 2: By a similar procedure, the analogous dark orange [Zn(isambz) $\mathrm{Cl}_{2}$ ] was prepared, using zinc(II) chloride instead of copper salt. In this case, a 1:1 metal:ligand complex was isolated, maintaining the $\mathrm{pH}$ around 9 during metalation. The yield was $58 \%$ (1.25 g). Elemental analyses: Calc. for $\mathrm{C}_{16} \mathrm{H}_{12} \mathrm{~N}_{4} \mathrm{OZnCl}_{2}$ (MW = 430.50): C, 44.64; H, 3.28; N, 13.01; Experim.: $C, 44.24 ; H, 3.11 ; N, 12.77$. UV/Vis: $\lambda_{\max }=259 \mathrm{~nm}\left(\varepsilon=8.85 \times 10^{-3} \mathrm{M}^{-1} \cdot \mathrm{cm}^{-1}\right), \lambda_{\max }=284 \mathrm{~nm}$ $\left(\varepsilon=8.67 \times 10^{-3} \mathrm{M}^{-1} \cdot \mathrm{cm}^{-1}\right)$. IR $\left(\mathrm{cm}^{-1}\right): 3344, v(\mathrm{~N}-\mathrm{H}) ; 2978, v \mathrm{C}_{\mathrm{sp} 2}-\mathrm{H}$ and $\left.\mathrm{C}=\mathrm{C}\right) ; 1721, v(\mathrm{C}=\mathrm{O}), 1613$ and $1471, v(\mathrm{C}=\mathrm{N}$ Schiff base, isatin ring and $\mathrm{N}-\mathrm{H}) ; 744, v(\mathrm{C}-\mathrm{H}$ phenyl $)$.

\subsection{Methods}

Elemental analyses (C, H, and N) were performed using a Perkin Elmer model 2400 analyzer (Perkin-Elmer, Billerica, MA, USA), and metal components were determined in duplicate by ICP emission spectroscopy in a Spectro Analytical Instruments equipment (Spectro/AMETEK, Kleve, Germany), at Central Analítica of our institution. UV/Vis spectra were registered in a UV-1650PC spectrophotometer from Shimadzu (Shimadzu Corp., Kyoto, Japan), using $1.00 \mathrm{~cm}$ optical length quartz cells. Fourier transform infrared (FTIR) spectra of samples were recorded in the $4000-400 \mathrm{~cm}^{-1}$ range on a Bruker FTIR ALPHA (Bruker, Billerica, USA) equipped with a single reflection diamond ATR module with a spectral resolution of $4 \mathrm{~cm}^{-1}$. EPR experiments were conducted in a Bruker EMX spectrometer operating at X-band (standard conditions: frequency 9.51 GHz, microwave power $20.12 \mathrm{~mW}$, modulation frequency $100 \mathrm{kHz}$ ) (Bruker, Karlsruhe, Germany), using Wilmad flat cells. HSA-radical was registered directly, at room temperature, after incubation of the protein with complex 1 or [Cu(isaepy)] $(100 \mu \mathrm{M})$, and immediately after addition of hydrogen peroxide (2.5 mM). 5,5-Dimethyl-1-pyrroline N-oxide (DMPO, $100 \mathrm{mM}$ ) and 4-hydroxy-1-oxyl-2,2,6,6-tetramethylpiperidine (Tempol, $36 \mu \mathrm{M}$ ) were used as spin trap and calibrant 
respectively, in spin trapping EPR experiments, to detect hydroxyl radical generation in the presence of hydrogen peroxide and complex 1.

\subsubsection{Interactions with Biomolecules Monitored by CD Spectroscopy}

Interactions of complex 1 with HSA were monitored by circular dichroism (CD) spectroscopy, in the range 190 to $300 \mathrm{~nm}$, in a JASCO J-720 spectropolarimeter. The spectra (double scan) were registered in a spherical quartz cell $(0.10 \mathrm{~cm}$ optical path), after increasing addition of complex 1 (stock solution $1.0 \mathrm{mM}$ ) to HSA solution $(2.5 \mu \mathrm{M})$, in phosphate buffer $50 \mathrm{mM}$ containing $0.10 \mathrm{M}$ $\mathrm{NaCl}$, at $\mathrm{pH} 7.4$ at room temperature. Results were expressed as residual elipsicity $(\theta)$, defined as $\theta$ $\left(\mathrm{deg} \mathrm{cm}{ }^{2} / \mathrm{dmol}\right)=\mathrm{CD}(\mathrm{mdeg}) / 10 \times \boldsymbol{n} \times \boldsymbol{l} \times \mathrm{C}_{\mathbf{p}}$, where CD is the measure in mdeg, $\boldsymbol{n}$ is the number of amino acid residues (for HSA, $n=585$ ), $l$ is the optical path, and $C_{p}$ is the protein concentration [40].

Binding to DNA was monitored through a typical DNA band at $270-280 \mathrm{~nm}$, using the same instrument, a JASCO J-720 spectropolarimeter (JASCO Inc., Easton, MD, USA). Decreasing intensity of this band (DNA $50 \mu \mathrm{M}$ ) was verified by addition of increasing concentrations of complex $\mathbf{1}$ or $\mathbf{2}$, up to $250 \mu \mathrm{M}$.

\subsubsection{Monitoring HSA Damage}

Oxidation of the protein was detected by following the formation of carbonyl groups through reaction with dinitrophenylhydrazine (DNPH) [41], after incubation of HSA with the copper complex 1 for $30 \mathrm{~min}$ at $37^{\circ} \mathrm{C}$, in the presence of hydrogen peroxide.

Samples of HSA $(75 \mu \mathrm{M})$ were incubated with hydrogen peroxide $(750 \mu \mathrm{M})$ and different concentrations of copper complex 1 at $37^{\circ} \mathrm{C}$ for $30 \mathrm{~min}$. To each sample was added $1 \mathrm{~mL}$ of $0.10 \mathrm{M}$ $\mathrm{DNPH}$ solution in $\mathrm{HCl} 1 \mathrm{M}$, and the mixture was incubated for more $30 \mathrm{~min}$ at the same temperature. After cooling, $1.5 \mathrm{~mL}$ of $1 \mathrm{M} \mathrm{NaOH}$ solution was added, and the formation of corresponding dinitrophenylhydrazones was monitored spectrophotometrically, at $370 \mathrm{~nm}\left(\varepsilon=22,000 \mathrm{M}^{-1} \cdot \mathrm{cm}^{-1}\right)$ [42].

\subsubsection{Fluorescence Measurements with DNA and Ethidium Bromide}

The fluorescence assays were performed by using fixed concentrations of CT-DNA $(30 \mu \mathrm{M})$ and ethidium bromide $(\mathrm{EtBr}, 50 \mu \mathrm{M})$, and adding varying concentration of each metal complex as a quencher $(20-3000 \mu \mathrm{M})$. The CT-DNA concentration per nucleotide was determined by absorption spectrometry with a molar extinction coefficient value of $6600 \mathrm{M}^{-1} \cdot \mathrm{cm}^{-1}$ at $260 \mathrm{~nm}$. A SPEX-Fluorolog 2 spectrometer (Horiba Scientific, Kyoto, Japan) was used in fluorescence intensity measurements, with excitation wavelength at $510 \mathrm{~nm}$ and emission wavelength in the range of $530-800 \mathrm{~nm}$. All these measurements were made by taking fresh solution each time in a quartz cell with $1.00 \mathrm{~cm}$ optical path, and the acquisitions were performed at $37^{\circ} \mathrm{C}$ under lower and constant stirring. The maximum fluorescence resembles at $587 \mathrm{~nm}$, and the first acquisition for each set of data was made in the absence of the quencher (complex). The initial fluorescence intensity was called $F_{0}$, and the subsequent fluorescence intensities at a fixed solution concentration were entitled as $F$.

To describe the fluorescence quenching of the EtBr in a competitive reaction between CT-DNA and the complexes $\left[\mathrm{Cu}(\text { isambz) })_{2}\right]^{2+} \mathbf{1}$ and $[\mathrm{Zn} \text { (isambz) }]^{2+} \mathbf{2}$, two different mathematical methods were used. The first method describes a dynamic process in which the quenching mechanism is mainly due to collision and can be described by the linear Stern-Volmer equation [43], $F_{0} / F=1+K_{\mathrm{q}} \tau_{0}[\mathrm{Q}]=1+$ $K_{\mathrm{Sv}}[Q]$, where $F_{0}$ and $F$ represent the fluorescence intensities in the absence and in the presence of different quencher concentration [Q] in mole per liter, respectively. The product $K_{\mathrm{q}} \tau_{0}$ is known as the Stern-Volmer constant, $K_{\mathrm{SV}}$, and it is a parameter that responds to the availability of the quencher to the fluorophore. The fluorophore quenching rate constant is given by $K_{\mathrm{q}}, K_{\mathrm{SV}}$ is the quenching constant, and $\tau_{0}$ is the lifetime of the fluorophore in the absence of a quencher. When non linearity occurs in the experimental data, the quenching mechanism is not purely collisional. This variation may be due either to the ground state complex formation or to the static quenching model [44]. The second method, described using the expression $\log \left[\left(F_{0}-F\right) / F\right]=\log K_{\mathrm{A}}+n \log [\mathrm{Q}]$, expresses the binding 
constant and the number of binding sites per nucleotide $(n)$ for the new species formed between the studied compound and the CT-DNA. The linear correlation $\log \left[\left(F_{0}-F\right) / F\right]$ versus $\log [Q]$ gives an equation where the slope corresponds to the binding stoichiometry $(n)$, and the intercept gives the $K_{\mathrm{a}}$ $\left(10^{\text {intecept }}=K_{\mathrm{a}}\right)$. In our experiments, fitting was restricted up to $400 \mu \mathrm{M}$ quencher concentration.

\subsubsection{DNA Cleavage Studies}

In these experiments, the plasmid pBluescript II (Stratagene, San Diego, USA) was used after purification, using Qiagen plasmid purification kit (Qiagen, Hilden, Germany). Mixtures of $240 \mathrm{ng}$ of supercoiled DNA (Form I), in $20 \mu \mathrm{L}$ total volume containing $50 \mathrm{mM}$ phosphate buffer ( $\mathrm{pH} 7.4$ ), in the presence or absence of hydrogen peroxide and varying concentrations of complex $\mathbf{1}$ were incubated at $37^{\circ} \mathrm{C}$ for different periods of time. Stock solutions of the complexes $(1.0 \mathrm{mM})$ were prepared by dissolving them in small amounts of dimethylsulfoxide (DMSO, 0.5 to $1 \mathrm{~mL}$ ), and immediately diluting appropriate samples to the desired concentration with buffer solution. The final amount of DMSO was $\leq 1 \%$. After incubation, a quench buffer solution $(4 \mu \mathrm{L})$ was added, and the final solution was subjected to electrophoresis on an $1 \%$ agarose gel in $1 \times$ TAE buffer ( $40 \mathrm{mM}$ Tris-acetate, $1 \mathrm{mM}$ EDTA) at $100 \mathrm{~V}$, for $2 \mathrm{~h}$.

\subsubsection{Cytotoxicity Assays In Vitro}

Human hepatoma cells, HepG2, and neuroblastoma cells, SHSY5Y, were purchased from the European Cell Culture Collection and grown in RPMI 1640 supplemented with $10 \%$ fetal calf serum, and in Dulbecco's modified Eagle's/F12 medium supplemented with 15\% fetal calf serum, respectively, at $37^{\circ} \mathrm{C}$ in an atmosphere of $5 \% \mathrm{CO}_{2}$ in air.

Cells were routinely trypsinized and plated at $30 \times 10^{5} / 75 \mathrm{~cm}^{2}$ flasks until sub-confluence. For the experiments, cells were plated on multiwell at $2 \times 10^{5} \mathrm{cells} / \mathrm{ml}$ and treated after $24 \mathrm{~h}$. The complexes were dissolved in DMSO (stock solution $1.0 \mathrm{mM}$ ), and used at different concentrations $(1 \mu \mathrm{M}, 10 \mu \mathrm{M}$, $25 \mu \mathrm{M}$, and $50 \mu \mathrm{M})$. Cytotoxicity assay was performed at $24 \mathrm{~h}$. Cells were collected in the medium by a scraper and harvested by centrifugation at $1000 \mathrm{rpm} \times 5 \mathrm{~min}$. Cell pellets were washed once in phosphate buffer solution, $\mathrm{pH}$ 7.4. Cell viability was estimated by direct count with a Toma's chamber upon Trypan blue exclusion.

\section{Conclusions}

Two novel complexes were obtained with an oxindolimine ligand, and had their oxidative properties toward HSA and DNA verified. Their cytotoxicities against tumor cells (HepG2 and SHSY5Y) were verified to be only moderate, in comparison to similar copper(II) complexes in the literature, and were then correlated with these oxidative properties, to clarify the main targets or modes of action of these studied complexes. This type of ligand exhibits tautomers in solution, depending on the $\mathrm{pH}$, leading to corresponding keto and enol forms of copper(II) or zinc(II) complexes (Figure 1, Scheme 1). In the case of zinc, the 1:1 metal:ligand complex was isolated, while for copper the 1:2 species was obtained by careful control of the $\mathrm{pH}$ during the synthesis. According to the overall results, in both cases the 1:1 species is probably the most active toward biomolecules at $\mathrm{pH} 7.4$, as already observed for other complexes in this series. However, in our studies we should consider the possibility of having both complexes 1:1 and 1:2 in equilibria, based on our previous studies with similar copper complexes, and on reported data in the literature for the speciation of different metallodrugs [45]. In this case, the predominant species detected in solution depends primarily on the $\mathrm{pH}$. The enol form of these oxindolimine ligands has a more delocalized electronic dispersion, in addition to a negative charge, since it is more easily deprotonated, and this usually leads to more stabilized and less sterically hindered metal center.

Both complexes 1 and $\mathbf{2}$ interact with HSA as well as with DNA, as detected by CD spectroscopy and fluorescence measurements, and are able to damage these biomolecules. Complex 1 is able to reasonably generate reactive oxygen species (ROS) up to $150 \mu \mathrm{M}$ concentration, but to a remarkable 
extent at concentration $\geq 200 \mu \mathrm{M}$, as detected by spin trapping EPR measurements. It causes oxidative damage to has, as monitored through carbonyl group formation, and significantly affects its $\alpha$-helix structure to a high extent. Additionally, a very stable protein-radical species was detected at $\mathrm{g}=1.989$ (width 52G) by EPR spectroscopy after treatment with complex 1 in the presence of $\mathrm{H}_{2} \mathrm{O}_{2}$ at room temperature. This radical was attributed to a protein-bound radical, HAS-Tyr- species, by comparison to a similar one, already identified in the literature, by treatment of bovine serum albumin (BSA) with $\mathrm{Cu}, \mathrm{Zn}$-superoxide dismutase, and hydrogen peroxide in the presence of nitrite [40]. Furthermore, this radical has been implicated in heme detoxification process by HSA, and seems to protect the protein against other potentially more toxic effects of this oxidant [41]. Therefore, the formation of such intermediary species attested to the remarkable oxidative properties of both copper(II) complexes investigated, complex $\mathbf{1}$ and $\left[\mathrm{Cu}(\text { isaepy })_{2}\right]^{2+}$. Interactions with HSA and other extracellular proteins can collaborate to decrease the amount of complexes entering the cells, and therefore contribute to their lower observed cytotoxicity.

The copper complex $\mathbf{1}$ is also capable of oxidizing DNA at very low $\mathrm{IC}_{50}$, in $\mathrm{nM}$ concentration range, in the presence of hydrogen peroxide $(50 \mu \mathrm{M})$. It leads to single and double strand cleavage after 60 min incubation at $37^{\circ} \mathrm{C}$, despite not binding remarkably to DNA by intercalation, as attested by fluorescence quenching in competitive measurements with EtBr. Compared to other copper complexes with analogous ligands, this new copper compound showed much better oxidative properties, although it exhibited only moderate anti-proliferative effect against hepatocellular carcinoma $\left(\mathrm{HepG}_{2}\right)$ and neuroblastoma (SHSY5Y) tumor cells [29]. Additionally, the analogous zinc complex 2, with no redox properties, exhibited similar cytotoxic effects against the same tumor cells. The ligand structure can be crucial for metal activity toward DNA, as exemplified in comparative studies of copper(II) complexes with correlated ligands, 2,2'-bipyridine (bpy), 2,2'-dipyridylamine (dpa) or dipicolylamine (dpca), where $\left[\mathrm{Cu}(\mathrm{bpy})_{2}\right]^{2+}$ complex was the most active in double cleavage reaction [46].

These data can also be indicative of alternative targets inside the cell in addition to DNA, in a process modulated by the metal ion, by the ligand, as well as by the predominant metal-ligand species formed. This class of metal complexes has already shown good inhibition activity toward kinases [31] and topoisomerases [32], and the remarkable ability to damage mitochondria [30].

These results point to other factors than oxidative assets in determining the reactivity of these compounds. A more voluminous and sterically hindered ligand can be responsible for the verified decreased toxicity of complexes $\mathbf{1}$ and 2, due to difficulties in entering the cell or intercalating at DNA structure. Their low solubility in aqueous solution is also a factor to consider. More recent studies in the development of metallodrugs use the strategy of inserting the active compounds into nanostructured materials, trying to increase their stability and efficiency in achieving their biological targets, as well enhancing anticancer activity. $[\mathrm{Cu}(\mathrm{phen})] \mathrm{Cl}_{2}$ complex, an inhibitor of aquaporin, was successfully incorporated into different liposomes, preserving its cytotoxicity against different tumor cells [47]. These copper loaded liposomes seem to have therapeutic potential for the treatment of solid tumors, based on their preferential accumulation. In other investigations, two correlated oxindolimine complexes based on copper and zinc, for which the anticancer properties had been already verified [29] were immobilized in functionalized nanoporous silica, and the obtained materials exhibited increased antiproliferative activity against melanomas [48]. They were monitored inside the cells, and released the active compounds in a kinetic process that depended on the metal. For the copper based materials, a $98 \%$ release was observed after $24 \mathrm{~h}$ at $37^{\circ} \mathrm{C}$, while for the analogous zinc based materials an $80 \%$ or $55 \%$ release could be verified, depending on the matrix used.

Our results confirmed DNA as an important target for these oxindolimine-metal complexes, as already observed [29], and additionally pointed out that oxidative damage is not the leading mechanism responsible for the cytotoxicity of this class of compounds.

Supplementary Materials: The following are available online at http:/ /www.mdpi.com/2304-6740/7/2/12/s1. Figure S1: Monitoring HSA damage in the presence of hydrogen peroxide and copper complexes. Figure S2: Quenching of CT-DNA/EB fluorescence by complexes 1 or 2. 
Author Contributions: All the co-authors contributed to this work. In conceptualization, A.M.D.C.F. and M.R.C.; methodology, M.C., Q.A.d.P., and P.C.; formal analysis, M.C., A.M.L.Z., Q.A.d.P., M.B.P., and P.C.; investigation, M.C., A.M.L.Z., Q.A.d.P., M.B.P., and P.C.; resources, A.M.D.C.F., C.C.O. and M.R.C.; data curation, A.M.D.C.F., C.C.O., and M.R.C.; writing—original draft preparation, M.C., A.M.L.Z., Q.A.d.P., A.M.D.C.F., and M.R.C.; writing-review and editing, A.M.D.C.F., C.C.O. and M.R.C.; project administration, A.M.D.C.F.; funding acquisition, A.M.D.C.F., C.C.O., and M.R.C.

Funding: This research was funded by Fundação de Amparo à Pesquisa do Estado de São Paulo (FAPESP, grant 11/50318-1); Coordenação de Aperfeiçoamento de Pessoal de Nível Superior (CAPES, Finance code 001); Programa Executivo de Cooperação Científica e Tecnológica Brasil-Itália, Conselho Nacional para o Desenvolvimento Científico e Tecnológico (CNPq)/Ministeri degli Affari Esteri (grant 490021/2008-5), and network CEPID Redoxoma (Redox Processes in Biomedicine, grant FAPESP 2013/07937-8).

Acknowledgments: Financial support from the Brazilian agencies (FAPESP, CAPES and CNPq), International Program for Scientific Collaboration Brazil-Italy (CNPq/Ministeri degli Affari Esteri), and network CEPID Redoxoma is gratefully acknowledged. M.C. and Q.A.P. also thank FAPESP for fellowships (2008/54470-0 and 2011/50204-6) during Post-doctoral studies.

Conflicts of Interest: The authors declare no conflict of interest.

\section{References}

1. World Health Organization. Cancer. Available online: http://www.who.int/news-room/fact-sheets/detail/ cancer (accessed on 18 October 2018).

2. Barry, N.P.E.; Sadler, P.J. Exploration of the medical periodic table: Towards new targets. Chem. Commun. 2013, 49, 5106-5131. [CrossRef] [PubMed]

3. Muhammad, N.; Guo, Z. Metal-based anticancer chemotherapeutic agents. Curr. Opin. Chem. Biol. 2014, 19, 144-153. [CrossRef] [PubMed]

4. Barone, G.; Terenzi, A.; Lauria, A.; Almerico, A.M.; Leal, J.M.; Busto, N.; García, B. DNA-binding of nickel(II), cooper(II) and zinc(II) complexes: Structure-affinity relationships. Coord. Chem. Rev. 2013, 257, $2848-2862$. [CrossRef]

5. Yu, Y.; Cui, Y.; Niedernhofer, L.J.; Wang, Y. Occurrence, biological consequences, and human health relevance of oxidative stress-induced DNA damage. Chem. Res. Toxicol. 2016, 29, 2008-2039. [CrossRef] [PubMed]

6. Qiu, K.; Chen, Y.; Rees, T.W.; Ji, L.; Chao, H. Organelle-targeting metal complexes: From molecular design to bio-applications. Coord. Chem. Rev. 2019, 378, 66-86. [CrossRef]

7. Bergamo, A.; Dyson, P.J.; Sava, G. The mechanism of tumour cell death by metal-based anticancer drugs is not only a matter of DNA interactions. Coord. Chem. Rev. 2018, 360, 17-33. [CrossRef]

8. Hanahan, D.; Weinberg, R.A. Hallmarks of cancer: The next generation. Cell 2011, 144, 646-674. [CrossRef] [PubMed]

9. $\quad$ Feng, L.; Geisselbrecht, Y.; Blanck, S.; Wilbuer, A.; Atilla-Gokcumen, G.E.; Filippakopoulos, P.; Kräling, K.; Celik, M.A.; Harms, K.; Maksimoska, J.; et al. Structurally sophisticated octahedral metal complexes as highly selective protein kinase inhibitors. J. Am. Chem. Soc. 2011, 133, 5976-5986. [CrossRef]

10. Neves, A.P.; Pereira, M.X.; Peterson, E.J.; Kipping, R.; Vargas, M.D.; Silva, F.P., Jr.; Carneiro, J.W.; Farrell, N.P. Exploring the DNA binding/cleavage, cellular accumulation and topoisomerase inhibition of 2-hydroxy-3-(aminomethyl)-1,4-naphthoquinone Mannich bases and their platinum(II) complexes. J. Inorg. Biochem. 2013, 119, 54-64. [CrossRef]

11. Kelly, W.K.; Connor, O.A.; Marks, P.A. Histone Deacetylase Inhibitors: From Target to Clinical Trials. Expert Opin. Investig. Drugs 2002, 11, 1695-1713. [CrossRef]

12. Santini, C.; Pellei, M.; Gandin, V.; Porchia, M.; Tisato, F.; Marzano, C. Advances in copper complexes as anticancer agents. Chem. Rev. 2014, 114, 815-862. [CrossRef] [PubMed]

13. Deo, K.M.; Pages, B.J.; Ang, D.L.; Gordon, C.P.; Aldrich-Wright, J.R. Transition metal intercalators as anticancer agents-Recent advances. Int. J. Mol. Sci. 2016, 17, 1818. [CrossRef] [PubMed]

14. Fu, X.B.; Liu, D.D.; Lin, Y.; Hu, W.; Mao, Z.W.; Le, X.Y. Water-soluble DNA minor groove binders as potential chemotherapeutic agents: Synthesis, characterization, DNA binding and cleavage, antioxidation, cytotoxicity and HSA interactions. Dalton Trans. 2014, 43, 8721-8737. [CrossRef] [PubMed]

15. McGivern, T.J.P.; Afsharpour, S.; Marmion, C.J. Copper complexes as artificial DNA metallonucleases: From Sigman's reagent to next generation anti-cancer agent? Inorg. Chim. Acta 2018, 472, 12-39. [CrossRef] 
16. Erxleben, A. Interactions of copper complexes with nucleic acids. Coord. Chem. Rev. 2018, 360, 92-121. [CrossRef]

17. Cao, Q.; Li, Y.; Freisinger, E.; Qin, P.Z.; Sigel, R.K.O.; Mao, Z.W. G-quadruplex DNA targeted metal complexes acting as potential anticancer drugs. Inorg. Chem. Front. 2017, 4, 10-32. [CrossRef]

18. Hansel-Hertsch, R.; Di Antonio, M.; Balasubramanian, S. DNA G-quadruplexes in the human genome: Detection, functions and therapeutic potential. Nat. Rev. Mol. Cell Biol. 2017, 18, 279-284. [CrossRef]

19. Bonsignore, R.; Russo, F.; Terenzi, A.; Spinello, A.; Lauria, A.; Gennaro, G.; Almerico, A.M.; Keppler, B.K.; Barone, G. The interaction of Schiff Base complexes of nickel(II) and zinc(II) with duplex and G-quadruplex DNA. J. Inorg. Biochem. 2018, 178, 106-114. [CrossRef]

20. Slator, C.; Molphy, Z.; McKee, V.; Long, C.; Brown, T.; Kellett, A. Di-copper metallodrugs promote NCI-60 chemotherapy via singlet oxygen and superoxide production with tandem TA/TA and AT/AT oligonucleotide discrimination. Nucleic Acids Res. 2018, 1. [CrossRef]

21. Vine, K.L.; Matesic, L.; Locke, J.M.; Skropeta, D. Recent Highlights in the Development of Isatin-Based Anticancer Agents. In Advances in Anticancer Agents in Medicinal Chemistry; Bentham Science: Oak Park, IL, USA, 2013; Volume 2, pp. 254-312. ISBN 978-1-60805-715-3.

22. Sridhar, S.K.; Ramesh, A. Synthesis and pharmacological activities of hydrazones, Schiff and mannich bases of isatin derivatives. Biol. Pharm. Bull. 2001, 24, 1149-1152. [CrossRef]

23. Cerchiaro, G.; Ferreira, A.M.D. Oxindoles and copper complexes with oxindole-derivatives as potential pharmacological agents. J. Braz. Chem. Soc. 2006, 17, 1473-1485. [CrossRef]

24. Karali, N. Synthesis and primary cytotoxicity evaluation of new 5-nitroindole-2,3-dione derivatives. Eur. J Med. Chem. 2002, 37, 909-918. [CrossRef]

25. Evdokimov, N.M.; Magedov, I.V.; McBrayer, D.; Kornienko, A. Isatin derivatives with activity against apoptosis-resistant cancer cells. Bioorg. Med. Chem. Lett. 2016, 26, 1558-1560. [CrossRef] [PubMed]

26. Prakash, C.R.; Theivendren, P.; Raja, S. Indolin-2-Ones in Clinical Trials as Potential Kinase Inhibitors: A Review. Pharmacol. Pharm. 2012, 3, 62-71. [CrossRef]

27. Cerchiaro, G.; Micke, G.A.; Tavares, M.F.M.; da Costa Ferreira, A.M. Kinetic studies of carbohydrate oxidation catalyzed by novel isatin-Schiff base copper(II) complexes. J. Mol. Catal. A Chem. 2004, 221, 29-39. [CrossRef]

28. Cerchiaro, G.; Aquilano, K.; Filomeni, G.; Rotilio, G.; Ciriolo, M.R.; Ferreira, A.M.D. Isatin-Schiff base copper(II) complexes and their influence on cellular viability. J. Inorg. Biochem. 2005, 99, 1433-1440. [CrossRef]

29. Filomeni, G.; Cerchiaro, G.; Ferreira, A.M.D.; De Martino, A.; Pedersen, J.Z.; Rotilio, G.; Ciriolo, M.R. Pro-apoptotic activity of novel isatin-Schiff base copper(II) complexes depends on oxidative stress induction and organelle-selective damage. J. Biol. Chem. 2007, 282, 12010-12021. [CrossRef]

30. Filomeni, G.; Piccirillo, S.; Graziani, I.; Cardaci, S.; Da Costa Ferreira, A.M.; Rotilio, G.; Ciriolo, M.R. The isatin-Schiff base copper(II) complex $\mathrm{Cu}\left(\right.$ isaepy) ${ }_{2}$ acts as delocalized lipophilic cation, yields widespread mitochondrial oxidative damage and induces AMP-activated protein kinase-dependent apoptosis. Carcinogenesis 2009, 30, 1115-1124. [CrossRef]

31. Miguel, R.B.; Petersen, P.A.D.; Gonzales-Zubiate, F.A.; Oliveira, C.C.; Kumar, N.; Nascimento, R.R.; Petrilli, H.M.; Da Costa Ferreira, A.M. Inhibition of cyclin-dependent kinase CDK1 by oxindolimine ligands and corresponding copper and zinc complexes. J. Biol. Inorg. Chem. 2015, 20, 1205-1217. [CrossRef]

32. Castelli, S.; Gonçalves, M.B.; Katkar, P.; Stuchi, G.C.; Couto, R.A.A.; Petrilli, H.M.; Da Costa Ferreira, A.M. Comparative studies of oxindolimine-metal complexes as inhibitors of human DNA topoisomerase IB. J. Inorg. Biochem. 2018, 186, 85-94. [CrossRef]

33. Sakaguchi, U.; Addison, A.W. Spectroscopic and redox studies of some copper(II) complexes with biomimetic donor atoms: Implications for protein copper centres. J. Chem. Soc. Dalton Trans. 1979, 600-608. [CrossRef]

34. Bonini, M.G.; Fernandes, D.C.; Augusto, O. Albumin oxidation to diverse radicals by the peroxidase activity of $\mathrm{Cu}, \mathrm{Zn}$-superoxide dismutase in the presence of bicarbonate or nitrite: Diffusible radicals produce cysteinyl and solvent-exposed and -unexposed tyrosyl radicals. Biochemistry 2004, 43, 344-351. [CrossRef]

35. Huang, Y.; Shuai, Y.; Li, H.; Gao, Z. Tyrosine residues play an important role in heme detoxification by serum albumin. Biochim. Biophys. Acta 2014, 1840, 970-976. [CrossRef] [PubMed]

36. Da Silveira, V.C.; Luz, J.S.; Oliveira, C.C.; Graziani, I.; Ciriolo, M.R.; Ferreira, A.M.D. Double-strand DNA cleavage induced by oxindole-Schiff base copper(II) complexes with potential antitumor activity. J. Inorg. Biochem. 2008, 102, 1090-1103. [CrossRef] 
37. Da Silveira, V.C.; Benezra, H.; Luz, J.S.; Georg, R.C.; Oliveira, C.C.; Ferreira, A.M.D. Binding of oxindole-Schiff base copper(II) complexes to DNA and its modulation by the ligand. J. Inorg. Biochem. 2011, 105, 1692-1703. [CrossRef] [PubMed]

38. Wu, J.; Chen, W.; Yin, Y.; Zheng, Z.; Zou, G. Probing the cell death signaling pathway of HepG2 cell line induced by copper-1,10-phenanthroline complex. Biometals 2014, 27, 445-458. [CrossRef] [PubMed]

39. Robertazzi, A.; Magistrato, A.; de Hoog, P.; Carloni, P.; Reedjik, J. Density functional theory studies on copper phenanthroline complexes. Inorg. Chem. 2007, 46, 5873-5881. [CrossRef]

40. Kumar, Y.; Tayyab, S.; Muzammil, S. Molten-globule like partially folded states of human serum albumin induced by fluoro and alkyl alcohols at low pH. Arch. Biochem. Biophys. 2004, 426, 3-10. [CrossRef]

41. Requena, J.R.; Levine, R.L.; Stadtman, E.R. Recent advances in the analysis of oxidized proteins. Amino Acids 2003, 25, 221-226. [CrossRef]

42. Davies, M.J. Protein oxidation and peroxidation. Biochem. J. 2016, 473, 805-825. [CrossRef]

43. Lakowicz, J.R.; Weber, G. Quenching of fluorescence by oxygen. Probe for structural fluctuations in macromolecules. Biochemistry 1973, 12, 4161-4170. [CrossRef] [PubMed]

44. Giraddi, T.P.; Kadadevarmath, J.S.; Malimath, G.H.; Chikkur, G.C. Effect of solvent on the fluorescence quenching of organic liquid scintillators by aniline and carbon tetrachloride. Appl. Radiat. Isot. 1996, 47, 461-466. [CrossRef]

45. Levina, A.; Crans, D.C.; Lay, P.A. Speciation of metal drugs, supplements and toxins in media and bodily fluids controls in vitro activities. Coord. Chem. Rev. 2017, 352, 473-498. [CrossRef]

46. Kwon, J.H.; Park, H.-J.; Chitrapriya, N.; Cho, T.-S.; Kim, S.; Kim, J.; Hwang, I.H.; Kim, C.; Kim, S.K. DNA cleavage induced by $\left[\mathrm{Cu}(\mathrm{L})_{x}\left(\mathrm{NO}_{3}\right)_{2}\right]\left(\mathrm{L}=2,2^{\prime}\right.$-dipyridylamine, 2,2'-bipyridine, dipicolylamine, $x=1$ or 2$)$ : Effect of the ligand structure. J. Inorg. Biochem. 2014, 131, 79-86. [CrossRef] [PubMed]

47. Nave, M.; Castro, R.E.; Rodrigues, C.M.P.; Casini, A.; Soveral, G.; Gaspar, M.M. Nanoformulations of a potent copper-based aquaporin inhibitor with cytotoxic effect against cancer cells. Nanomedicine 2016, 11, 1817-1830. [CrossRef] [PubMed]

48. Vieira, E.G.; Miguel, R.B.; da Silva, D.R.; Fazzi, R.B.; de Couto, R.A.A.; Marin, J.H.; Temperini, M.L.A.; Shinohara, J.S.; Toma, H.E.; Russo, L.C.; et al. Functionalized nanoparticles as adjuvant to increase the cytotoxicity of metallodrugs toward tumor cells. New J. Chem. 2019, 43, 386-398. [CrossRef] 